\title{
Principal Component Analysis of Male Criminal Behavior
}

\author{
Patricia Martínez-Lanz ${ }^{1 *}$, Carlos Cuevas-Covarrubias², Patricia Hernández-Valdez ${ }^{1}$ \\ ${ }^{1}$ Interdisciplinary Research Center, Universidad Anáhuac México, Mexico City, Mexico \\ ${ }^{2}$ Research Center of Statistics and Applied Mathematics, Universidad Anáhuac México, Mexico City, Mexico \\ Email: *pmlanz@anahuac.mx
}

How to cite this paper: Martínez-Lanz, P., Cuevas-Covarrubias, C. and HernándezValdez, P. (2021) Principal Component Analysis of Male Criminal Behavior. Health, 13, 1112-1128.

https://doi.org/10.4236/health.2021.131008 $\underline{3}$

Received: August 31, 2021

Accepted: October 23, 2021

Published: October 26, 2021

Copyright (c) 2021 by author(s) and Scientific Research Publishing Inc. This work is licensed under the Creative Commons Attribution International License (CC BY 4.0).

http://creativecommons.org/licenses/by/4.0/

\begin{abstract}
The present study was conducted in order to establish factors that can potentially facilitate crime, as well as the status of the emotional wellbeing presented in the prison population. The sample was composed of 358 inmates of the Federal Center for Social Rehabilitation number 7 in Mexico. A questionnaire was specifically developed; it evaluated sociodemographic factors and Likert scales of substance intake, domestic violence, and depressive symptoms. Validity and reliability (Cronbach's Alpha $=0.703$ ) of the instrument showed appropriate relations between the reagents of the scales; results showed-through Chi-Square analysis-statistically significant differences in the correlations between sociodemographic factors, domestic violence, addictions, and depressive symptoms. Although results showed a connection between domestic violence and substance abuse with criminal behavior, low socioeconomic conditions exhibited a higher degree of correlation with criminal activity. On the other hand, high depression symptoms are present in one out of every five inmates.
\end{abstract}

\section{Keywords}

Delinquency, Addictions, Violence, Depression, Crime, Criminal Behavior, Prison Population, Wellbeing

\section{Introduction}

\subsection{Criminal Behavior}

For over two decades, the world has been referring to Mexico as a violent country. The great numbers of confrontations between the State and the drug cartels, and among the cartels themselves, have left historic statistics: more than 100,000 deaths in 10 years, record numbers in homicides in states like Baja California, 
Chihuahua and Guerrero, international protests due to femicides and a reduction in life expectancy due to the same fact [1] [2]. A great number of materials have been written about homicide and its effects on Mexico. Mexican authorities sustain time after time that crime rates are on the decline, that they have leveled and that better data is now available. Complacently, it seems that those who insist on improved statistical data forget that less crime rates do not necessarily mean an improved quality of life or that the problem has been resolved. This is not just because official homicide rates represent only a part of the homicides effectuated in the country [3] [4].

Crimes are underreported due to institutional weaknesses, poor operational performance by prosecutorial personnel, and a clear write-off of forced and involuntary disappearances and the possible link of these crimes with the discovery of multiple clandestine mass graves. Criminal behavior and violence stand out among statistical records as the main problems faced by Mexicans, generalizing the crisis of institutions.

According to the National Citizen Observatory for Security, Justice and Legality (ONC), 9 out of every 10 high-impact crimes in October 2016 increased compared to the previous month; similarly, investigation files reached their maximum annual levels. Under the common law, the most harmful crimes for the population, such as extortion or kidnapping, increased by $25 \%$ as compared with the rest of the year [5].

In this regard, the year 2017 begins with 2152 victims of homicide in its first month, increasing by 5.65\% compared to December; since July 2016 the number of victims of this crime has exceeded 2000 cases. Another crime that presented significant increases was business theft, from 7092 investigation folders in December to 8442 in January 2017, increasing by $19.04 \%$; it is worrying to observe significant rises in crimes against economic units that contribute to the country's growth. On the other hand, the investigation files for carjacking and home robbery also presented increases in this first month of the year.

It can be seen that the panorama is not favorable because the second half of last year was complicated, and data obtained from January show that the trend will not reverse.

\subsection{Domestic Violence}

Domestic violence and family abuse were not recognized as a social problem only until 1960 when some authors described the Abused Child Syndrome. In the past twenty years, several investigations showed that domestic violence, more specifically gender violence, is not so rare, and in many cases is exercised by the intimate partner or ex-spouse of the victim [6] [7].

Violent behavior is the use of force for the resolution of personal conflicts; it arises with the imbalance of power. With this behavior, the offender's goal is to subdue or subordinate the other member of the relationship, causing any kind of damage.

There are multiple causes for this phenomenon. Factors such as personality 
and family dynamics have been detected, and are related to the level of poverty and economic stress, as well as cultural norms that support gender violence or social inequality. From an epidemiological point of view, it is evident that domestic violence occurs in different forms against a variety of groups, such as women, children and adolescents. Violence within the couple's life arises through the difference between the roles traditionally attributed to both sexes, especially the women's inferiority respect to men, becoming one of the most important public health problems in the world [8] [9] [10].

In 2012, the Special Prosecutor's Office for Women Victims of Crime for Gender Reasons in Ciudad Juarez (Chihuahua, Mexico) reported 284 cases of domestic violence; a high number compared with sexual offenses (51 cases per month) or cases of non-compliance with alimony (17 cases per month). Most of the studies about gender violence have concentrated on the victim, leaving aside the role of the aggressor within the personal psychodynamic; in recent years, the number of publications about this issue is increasing, but it is not consolidated as a line of epidemiological research.

According to Alvarado-Zaldívar et al. [9], the most frequent type of domestic violence against women in Durango (Mexico) is sexual abuse, followed by physical and emotional violence. In most cases, physical violence is accompanied by emotional violence in the form of bullying and verbal abuse. The precursors of violence, such as alcoholism and drug abuse, are factors observed in the three types of violence.

\subsection{Substance Abuse}

Drug abuse and criminal behavior are complex and multifactorial phenomena, related to specific aspects of adolescent development, and risk factors. It is important to understand what makes people vulnerable to experimentation, abuse, or particular pathogenic behavior junction of several risk factors. In contrast, the presence of protective factors may promote their inhibition, reduction or modulation. The risk factors are [10] [11] [12] [13]:

1) Socio-cultural factors presented in a particular culture and historical moment: Availability of drugs and weapons; incorrect perception of drug use and violent behavior, and their consequences; the presence of economic deprivation, reception of erroneous information by the media.

2) Individual and interpersonal relationships. They may be:

a) Biological factors. Genetic susceptibility to alcoholism and mental illness; starting to use drugs before the age of 15 increases the risk of addictive behavior; alcoholism and drug abuse increase the probability of criminal conduct;

b) Psychological factors. Beliefs and expectations about drugs are directly related to their use and psychiatric problems such as anxiety, depression, ADHD, antisocial personality, schizophrenia and lack of empathy;

c) Family factors. Permissive parents without clear limits or authoritarian style do not allow youth development; positive attitudes towards drugs abuse, family conflicts, physical and sexual abuse; 
d) Academic factors. School failure, ADHD, maladjustment, poor relationship with peers;

e) Social factors. Group pressure, addicted friends and overestimated perception of drug abuse.

\subsection{Depression}

A depressive disorder is an illness that involves the body, mood, and thoughts. It interferes with daily life, normal functioning, and causes pain for both the person with the disorder and those who care about him or her. A depressive disorder is not the same as a passing blue mood. It is not a sign of personal weakness or a condition that can be willed away. Major depression is manifested by a combination of symptoms that interfere with the ability to work, study, sleep, eat, and enjoy once pleasurable activities. Such a disabling episode of depression may occur only once, but more commonly happens several times in a lifetime. Some forms of depressive disorder exhibit slightly different characteristics than those described above, or they may develop under unique circumstances.

Prisoners have an elevated risk of self-injurious behaviors and suicide [14]. Research examining vulnerable prisoners often focuses on sociodemographic risk factors (such as gender, age, ethnicity, penal status and offense type), and mental illness diagnoses.

Depressive disorder or depressive symptoms are particular common. Affective disorders have consistently been linked with vulnerability to self-injurious behaviors and suicide in prison. Social disadvantage and/or a specific set of circumstances may dispose prisoners to depression, exacerbating it by the stress of imprisonment [15].

Although many studies have identified depression or depressive symptoms as an important risk factor for self-harm, few have demonstrated which among them mediate this risk. Some studies have consistently identified "hopelessness" as the single most important predisposing variable in both prison/clinical and community samples [16].

Prison inmates in Mexico are reported to have substantially higher rates of depressive disorders than the general population, even after adjustment for demographic factor. Although our understanding of incarcerated populations has been significantly enriched by research in the past ten years, gaps in some subject areas, and the wide range of point estimates for some conditions, are a reflection of continued limitations on research and practice.

\section{Method}

The present investigation is a non-experimental, cross-sectional, exploratory, descriptive, and correlational study.

\subsection{Participants}

Since the participation of the inmates in the study was voluntary, the population was percentual distribution composed by a convenience sample of 358 male in- 
mates of the Federal Center for Social Rehabilitation number 7 in Durango, Mexico.

\subsection{Instrument}

A questionnaire composed of sociodemographic items and three scales (family violence, substance abuse, depressive symptoms) was designed and applied to the prisoners. Family violence scale and items related to substance abuse were designed, applied and validated previously in other inmate studies in México. Depression scale was also adapted and validated from Depression Scale of the Epidemiological Studies Center CESD in previous studies for imprisioned population. The scale was originally presented to inmates with 4 response options; however, the pilot tests showed that these options confused the inmates, therefore, for the purposes of this work, only the presence or absence of the symptom was taken into account with two response options: yes and no [17] [18] [19] [20].

Based on the test's validity and reliability, a Cronbach's Alfa of 0.703 and 0.702 was obtained which can be considered a fairly good level of confidence. The scales of domestic violence and depression reported a rotated factor analysis adecuate on the identification of 4 related factors each one.

\subsection{Process}

The self-applying and anonymous instrument explored sociodemographic factors, levels of domestic violence and the presence of addictions, criminal activity and manifestation of depression symptoms during their residence in prison.

\section{Results}

Regarding the sociodemographic data obtained from the inmates $(\mathrm{N}=358)$, it was found that (Table 1).

The age of the inmate population varies between 18 and 88 years old: $11.6 \%$ are between 18 and 27, 37\% are between 28 and 37, 30.3\% are between 38 and $47,14.2 \%$ are between 48 and 57, 11.6\% are between 18 and 27 , and finally $6.2 \%$ are 58 years old or more.

About marital status, the results show that $36.5 \%$ are married, the same percentage of inmates live in consensual union, while $24.1 \%$ are single and $2.8 \%$ are divorced.

The results about scholarship indicate that $39.8 \%$ of the inmate population went to middle school, $30.7 \%$ went to high school, $22.2 \%$ went to elementary school and $7.4 \%$ went to university.

The crime profile of the population (Table 2) point to drug trafficking as the most common offense in $66.7 \%$ of the cases, followed by homicide with $11.1 \%$, unspecified crimes with $6.3 \%$, kidnapping with $5.9 \%$, theft with $4.8 \%$, rape with $4.4 \%$ and forgery with $0.8 \%$. 
Table 1. Sociodemographic characteristics of the population.

\begin{tabular}{ccc}
\hline \multicolumn{2}{c}{ Characteristics } & Percentage \\
\hline \multirow{2}{*}{ Age } & 18 to 27 years & $11.6 \%$ \\
& 28 to 37 years & $37.7 \%$ \\
& 38 to 47 years & $30.3 \%$ \\
& 48 to 57 years & $14.2 \%$ \\
Marital Status & 58 years or more & $6.2 \%$ \\
\hline \multirow{3}{*}{ Scholarship } & Single & $24.1 \%$ \\
& Consensual Union & $36.5 \%$ \\
& Married & $36.5 \%$ \\
& Divorced & $2.8 \%$ \\
\hline & Elementary School & $22.2 \%$ \\
& Middle School & $39.7 \%$ \\
& High School & $30.7 \%$ \\
\hline
\end{tabular}

Table 2. Criminal characteristics of the population.

\begin{tabular}{|c|c|c|}
\hline \multicolumn{2}{|c|}{ Characteristics } & \multirow{2}{*}{$\begin{array}{c}\text { Percentage } \\
4.8 \%\end{array}$} \\
\hline \multirow{7}{*}{ Crime } & Theft & \\
\hline & Kidnapping & $5.9 \%$ \\
\hline & Rape & $4.4 \%$ \\
\hline & Drug trafficking & $66.7 \%$ \\
\hline & Homicide & $11.1 \%$ \\
\hline & Forgery & $0.8 \%$ \\
\hline & Others & $6.3 \%$ \\
\hline \multirow{5}{*}{ Sentence of imprisonment } & In process & $41.6 \%$ \\
\hline & Less than a year & $0.6 \%$ \\
\hline & 1 to 6 years & $11.9 \%$ \\
\hline & 7 to 20 years & $32.2 \%$ \\
\hline & More than 21 years & $13.7 \%$ \\
\hline \multirow{4}{*}{ Executed sentence } & Less than a year & $8.2 \%$ \\
\hline & 1 to 6 years & $64.2 \%$ \\
\hline & 7 to 20 years & $24.3 \%$ \\
\hline & More than 21 years & $3.3 \%$ \\
\hline
\end{tabular}

The sentence of imprisonment is, in $41.6 \%$ of the cases, in process; $32.2 \%$ of the prisoners have a pronounced sentence of 7 to 20 years, $13.7 \%$ more than 21 years, $11.9 \%$ about 1 to 6 years and $0.6 \%$ less than a year.

Regarding the sentence served, $64.2 \%$ of the male inmates have executed be- 
tween 1 to 6 years of their sentence, $24.3 \%$ from 7 to 20 years and $8.2 \%$ less than a year and $3.3 \%$ more than 21 years.

In terms of home characteristics of the population (Table 3), the results show that $50.1 \%$ of male inmates lived with their couple and children before imprisonment, and the rest with others or alone. The most important problem at home was: in $46.5 \%$ of the cases, unemployment; addiction in $29.8 \%$; infidelity in $17.8 \%$, and aggression (physical, verbal) in $5.9 \%$. By the same token, in $80.4 \%$ of cases the main cause of family problems was the male inmate.

Table 4 shows the occupational characteristics of the population: $50.6 \%$ of the inmates had from 2 to 4 jobs during the last 10 years prior to imprisonment. In terms of work activity, $45.1 \%$ were workers or artisans; $30.7 \%$ had an unspecified work, $21 \%$ were salesmen, office workers, or merchants, and $3.2 \%$ were professionals or managers. About the reason of waiver, $76.1 \%$ was the entry to prison.

Regarding the above, $58.1 \%$ of the population's monthly income was $\$ 157$ USD or more and $41.9 \%$ made $\$ 156.5$ USD or less; $78.4 \%$ of the inmates began their work lives when they were 8 to 16 years old, and $21.5 \%$ began with over 17 years of age. For $60.9 \%$ of the subjects, the reason to start working was to support their households economically.

The clinical scales that were applied, domestic violence before imprisonment and depressive symptoms during imprisonment (Table 5), showed that $89 \%$ of the population has low levels of domestic violence, $10 \%$ of inmates have high levels of violence, and $1 \%$ have severe levels of domestic violence. On the other hand, depressive symptoms are low in $75 \%$ of the cases, high in $21 \%$ and severe in $4 \%$.

According to the study, variables about alcoholic intake before imprisonment (Table 6): $62 \%$ of the participants consumed alcohol moderately, $22 \%$ had a high alcohol intake and $16 \%$ had a severe alcohol intake. Talking about substance abuse, $97 \%$ of inmates reported low intake and 3\% high level of consumption. There is no severe consumption reported.

Using the cross-tab analysis (Chi squared), the following correlations were obtained with statistically significant differences.

Table 3. Home characteristics of the population.

\begin{tabular}{|c|c|c|}
\hline & Characteristics & Percentage \\
\hline \multirow{4}{*}{ Problem at home } & Addiction & $29.8 \%$ \\
\hline & Aggression (physical, verbal) & $5.9 \%$ \\
\hline & Infidelity & $17.8 \%$ \\
\hline & Unemployment & $46.5 \%$ \\
\hline \multirow{3}{*}{$\begin{array}{l}\text { Responsible for the } \\
\text { problem at home }\end{array}$} & The inmate & $80.4 \%$ \\
\hline & The inmate's couple & $4.2 \%$ \\
\hline & $\begin{array}{l}\text { Others (inmate's parents, inmate's in laws, } \\
\text { inmate's relatives, inmate's friends) }\end{array}$ & $15.5 \%$ \\
\hline
\end{tabular}


Table 4. Occupational characteristics of the population.

\begin{tabular}{|c|c|c|}
\hline \multicolumn{2}{|c|}{ Characteristics } & \multirow{2}{*}{$\begin{array}{c}\text { Percentage } \\
29.8 \%\end{array}$} \\
\hline \multirow{4}{*}{ Jobs in the last 10 years } & One & \\
\hline & 2 to 4 jobs & $50.6 \%$ \\
\hline & 5 to 7 jobs & $9.1 \%$ \\
\hline & More than 7 jobs & $10.5 \%$ \\
\hline \multirow{4}{*}{ Occupation } & Professional, manager & $3.2 \%$ \\
\hline & Salesmen, office workers, merchants & $21 \%$ \\
\hline & Workers, artisans & $45.1 \%$ \\
\hline & Other & $30.7 \%$ \\
\hline \multirow{4}{*}{ Income } & $\$ 70.8$ USD & $19.9 \%$ \\
\hline & \$70.9 USD - \$156.5 USD & $22 \%$ \\
\hline & \$157 USD - \$260.8 USD & $25.8 \%$ \\
\hline & \$261 USD & $32.3 \%$ \\
\hline \multirow{4}{*}{ Age of first job } & Under 8 years & $13.9 \%$ \\
\hline & 9 to 12 years & $24.6 \%$ \\
\hline & 13 to 17 years & $39.9 \%$ \\
\hline & More than 17 years & $21.5 \%$ \\
\hline \multirow{5}{*}{ Reason for first job } & To economic home support & $60.9 \%$ \\
\hline & For personal interest & $31.4 \%$ \\
\hline & To pay for school & $3.7 \%$ \\
\hline & For the illness of a relative & $2 \%$ \\
\hline & For the pressure of a relative & $2 \%$ \\
\hline
\end{tabular}

Table 5. Clinical scales.

\begin{tabular}{|c|c|c|}
\hline \multicolumn{2}{|c|}{ Clinical scales } & \multirow{2}{*}{$\begin{array}{c}\text { Percentage } \\
89 \%\end{array}$} \\
\hline & Low & \\
\hline \multirow[t]{3}{*}{ Domestic Violence } & High & $10 \%$ \\
\hline & Severe & $1 \%$ \\
\hline & Low & $75 \%$ \\
\hline \multirow[t]{2}{*}{ Depressive symptoms } & High & $21 \%$ \\
\hline & Severe & $4 \%$ \\
\hline
\end{tabular}

Table 6. Substance consumption scales.

\begin{tabular}{ccc}
\hline \multicolumn{2}{c}{ Clinical scales } & Percentage \\
\hline \multirow{2}{*}{ Alcohol } & Moderate & $62 \%$ \\
& High & $22 \%$ \\
& Severe & $16 \%$ \\
\hline \multirow{2}{*}{ Substance abuse } & Moderate & $97 \%$ \\
& High & $3 \%$ \\
& Severe & $0 \%$ \\
\hline
\end{tabular}


By crossing the age of first job with motivation to work $(\mathrm{p}=0.000)$, people with the need to support their households economically started their work activity between 13 and 16 years of age (59.3\%), 9 to 12 years of age $(78.2 \%)$ and 8 years or less $(68.8 \%)$. The inmates who cited personal interest as the main reason to start working were over 17 years old when they started laboring (Figure 1).

The correlation between levels of depressive symptoms and levels of domestic violence $(\mathrm{p}=0.000)$, indicates that $50 \%$ of the inmate population with severe levels of domestic violence also present a severe level of depressive symptoms. The reason for this phenomenon is the impact of the instability and vulnerability of the family support in the inmate's mind, making them unable to face stressful events like imprisonment (Figure 2).

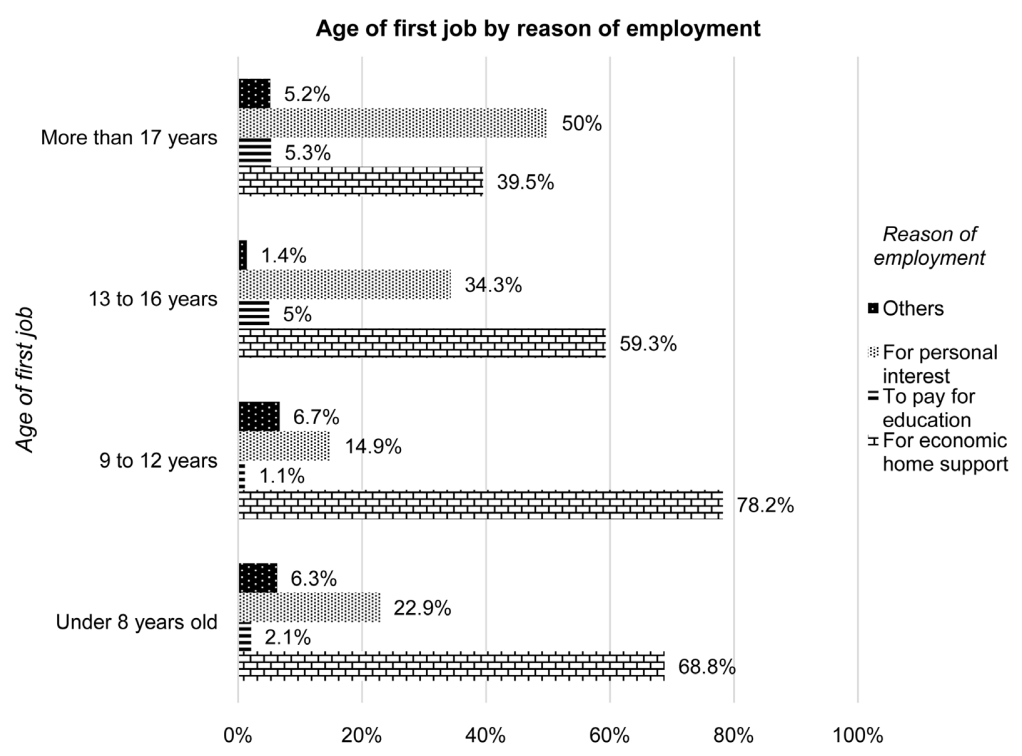

Figure 1. Age of first job by reason of employment.



Figure 2. Levels of depressive symptoms by levels of domestic violence. 
About the statistical relationship between levels of domestic violence with levels of alcohol intake $(\mathrm{p}=0.000)$, the result shows that $50 \%$ of the population with high levels of domestic violence reports a high level of alcohol consumption, as well as in the case of severe levels of domestic violence and severe levels of alcohol intake (50\%) (Figure 3). It is important to notice that the most addictive drug is alcohol, because of the continued exposure of young population to it, which enables the addictive consumption.

In order to identify the relation between levels of drug consumption and levels of domestic violence ( $p=0.000$ ), the study showed that in severe level of domestic violence, the substance abuse is also severe in $25 \%$ of inmates (Figure 4). This correlation shows how the physical and emotional violence at home damage the decision-making in topics such as substance consumption, combined with the main responsible for the domestic violence reported: the inmate.

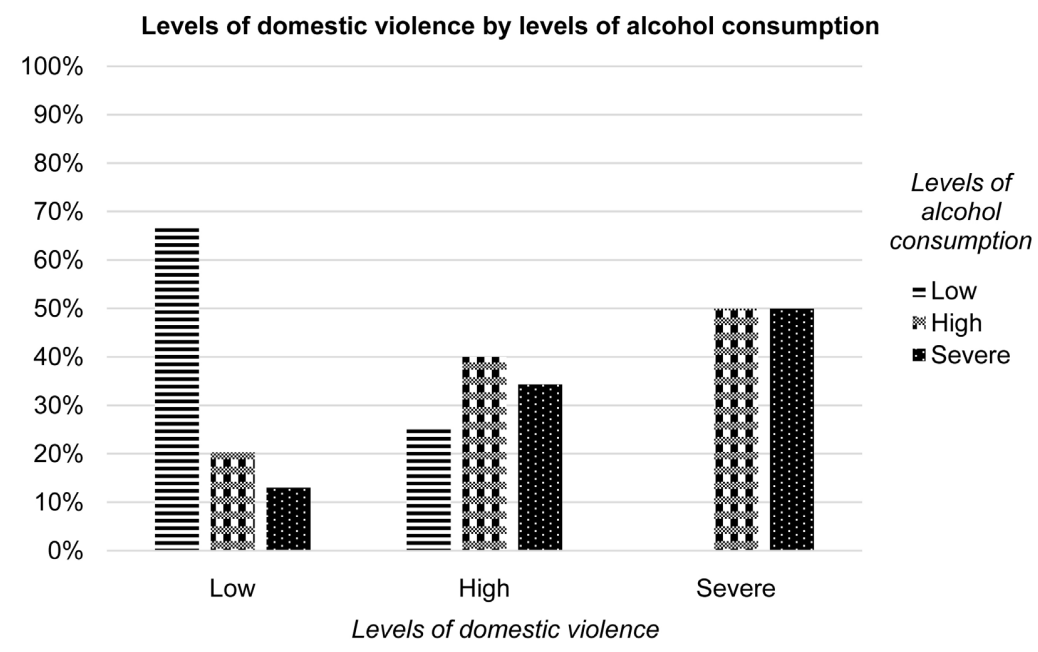

Figure 3. Levels of domestic violence by levels of alcohol consumption.

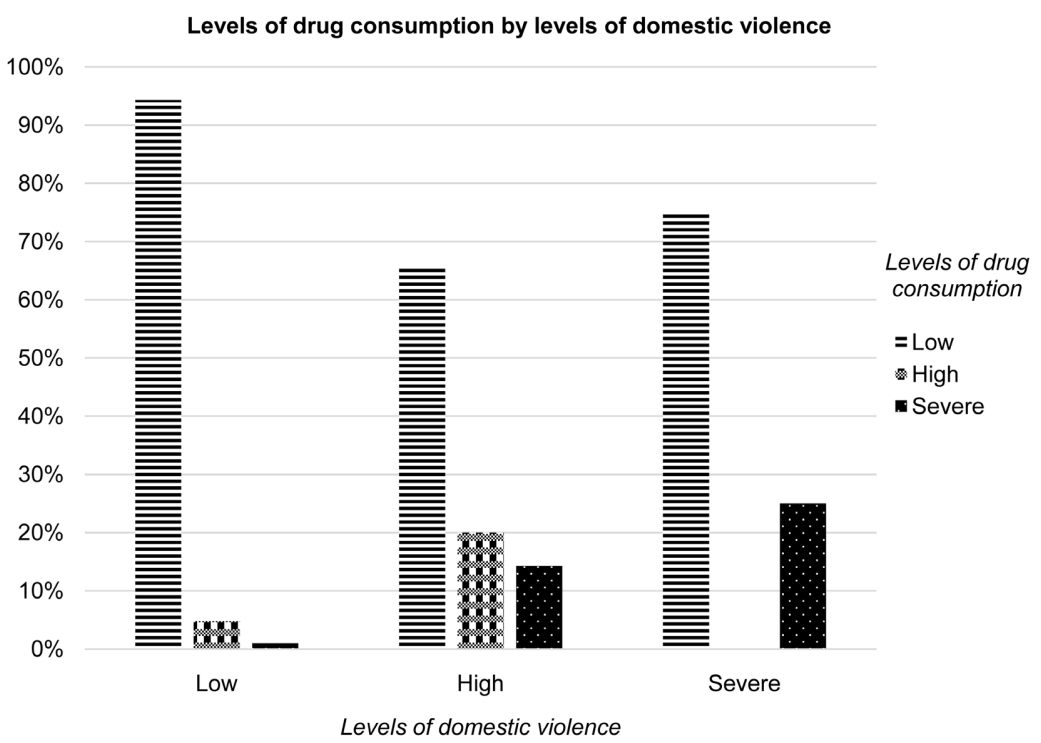

Figure 4. Levels of drug consumption by levels of domestic violence. 
In terms of levels of domestic violence, the male inmate with age of onset of substance abuse $(\mathrm{p}=0.000)$ between 9 to 17 years old is the most representative group in the low (47.4\%), high (93.8\%) and severe (100\%) levels of domestic violence, as shown in Figure 5. This result indicates the influence of the family environment in the moment of first contact with drugs, facilitating the substance abuse.

The type of use in each substance that was explored is mostly experimental: $85.1 \%$ for analgesics, $92.4 \%$ for tranquilizers, $91.3 \%$ for sedatives, $93 \%$ for amphetamines, $93.3 \%$ for inhalable, $68.7 \%$ for cannabis, $95.5 \%$ for hallucinogens, $65.2 \%$ for cocaine and $97.8 \%$ for heroin. In the case of cannabis, the habitual intake is $15.2 \%$ and the addictive intake, $16.1 \%$; cocaine reported a rate of $18.5 \%$ for habitual consumption and $16.3 \%$ for addictive consumption (Figure 6).

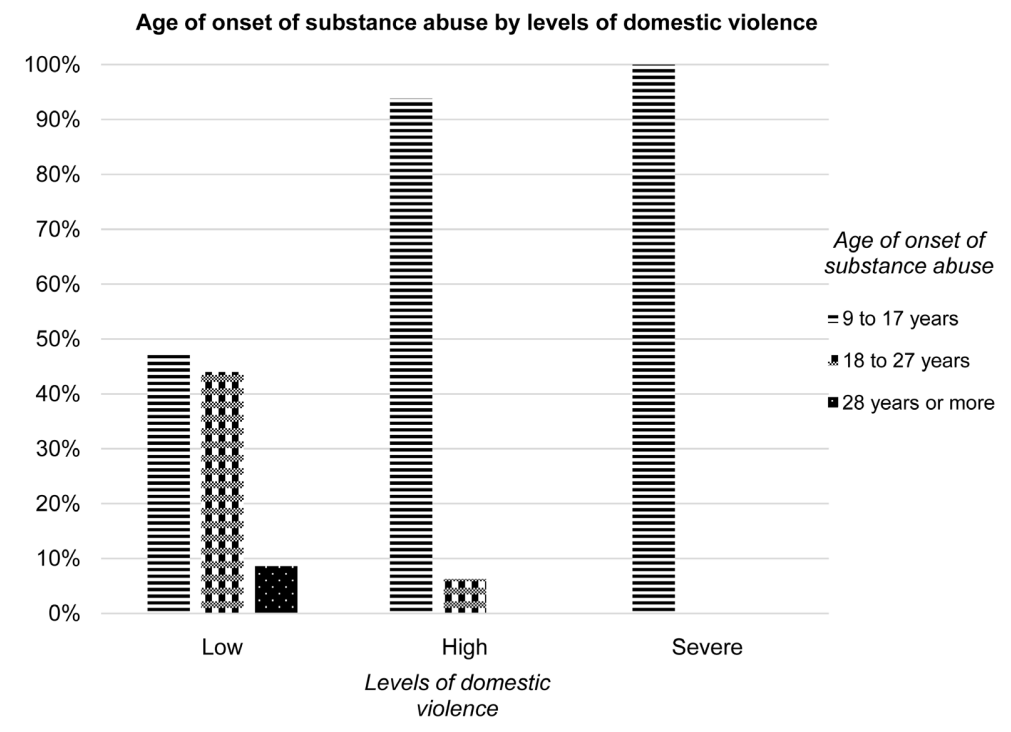

Figure 5. Age of onset of substance abuse by levels of domestic violence.

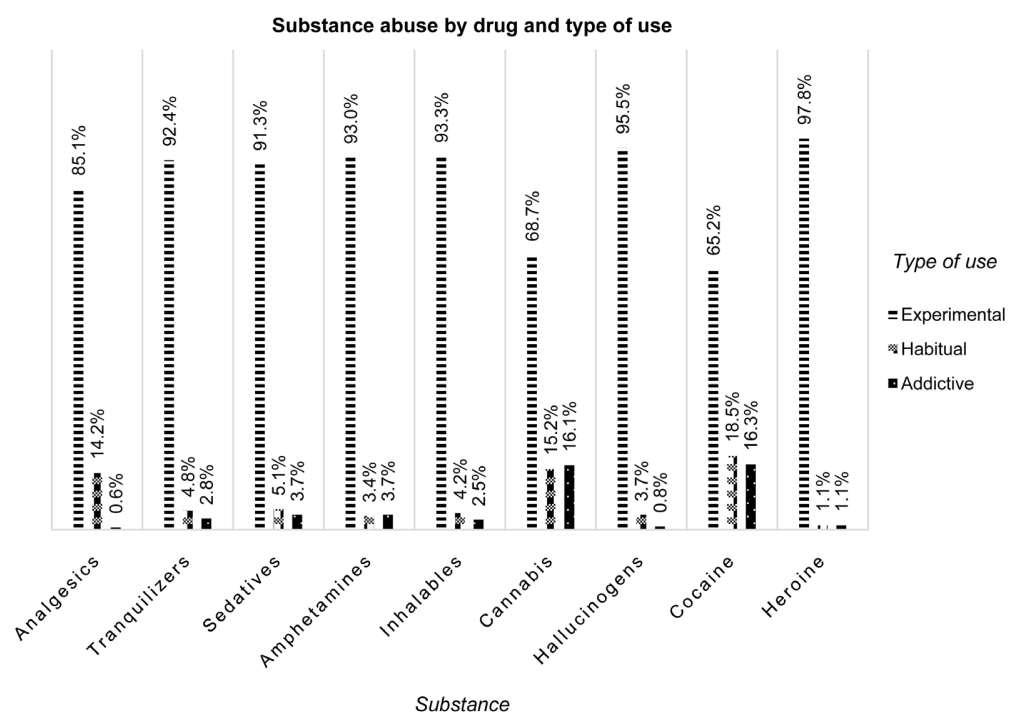

Figure 6. Substance abuse by type of use. 
In order to analyze the relation between variables and between categories of each variable, a correspondence analysis among type of crime and other study variables was carried out. In the analysis of type of crime due domestic violence, Chi square was 116.40 , with a correlation of $0.010(\mathrm{p}=0.077)$. About dimensions, the first one had a high level, with 0.204 of inertia, and the second one reported a low level, with 0.096 of inertia (Figure 7).

In order to carry out the Principal Component Analysis, three original variables were established: domestic violence, alcohol intake and substance abuse. On this basis, three new variables were calculated:

1) CP1. General index expresses the value of three variables. High rates of this component suggest high levels of domestic violence, alcohol consumption and substance abuse; low rates suggest low levels of each component. About the total information of the sample, CP1 represents $56 \%$.

2) CP2. It is the contrast between domestic violence vs. alcohol consumption and substance abuse. Negative values of this component suggest high levels of domestic violence and low levels of alcohol and substance abuse. Positive values suggest low levels of domestic violence and high levels of alcohol and substance abuse. About the total information of the sample, CP2 represents $23 \%$.

3) CP3. It is the contrast between alcohol and substance abuse, defining a consumption profile. Negative values of this component suggest alcohol intake, but not substance abuse; positive values suggest substance abuse, but not alcohol intake. About the total information of the sample, CP3 represents $21 \%$.

Based on the above, CP1 and CP2 were related, obtaining the following scatter plot (Figure 8).

The analysis of the quadrants showed that:

1) With high levels of domestic violence and addictions (substance abuse as the relevant problem) the inmate's age is between 28 and 37 years old at $48 \%$; 42.1\% have completed high school, and the age of fist job is between 9 and 16 years old at $77.4 \%$. The age of onset of substance abuse is between 18 and 27 years in $88.9 \%$; drug trafficking is the most committed crime in $66.7 \%$, followed by homicide (14.8\%) and kidnapping $(9.3 \%)$.

\begin{tabular}{cccccc}
\hline Dimension & Singular value & Inertia & Chi square & Significance & Correlation \\
\hline 1 & 0.452 & 0.204 & & & 0.010 \\
2 & 0.310 & 0.096 & & & \\
3 & 0.261 & 0.068 & & & \\
4 & 0.190 & 0.036 & & & \\
5 & 0.170 & 0.029 & & & \\
6 & 0.121 & 0.015 & & & \\
Total & & 0.448 & 116.405 & $0.077^{\mathrm{a}}$ & \\
\hline
\end{tabular}

Figure 7. Relation between variables and between categories of each variable. 


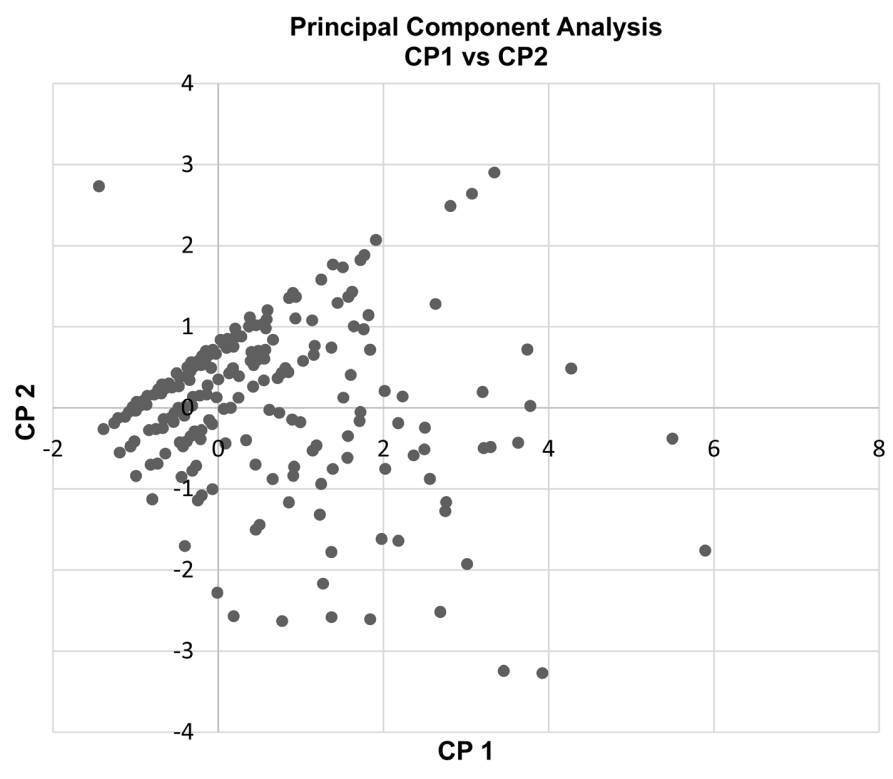

Figure 8. Principal component analysis: CP1 (domestic violence, alcohol intake and substance abuse) vs. CP2 (contrast between domestic violence vs. alcohol consumption and substance abuse).

2) With high levels of domestic violence and addictions (domestic violence as the relevant problem) the inmate's age is between 28 and 47 years old at $63.3 \%$; $70.8 \%$ have completed high school, and the age of fist job is between 13 and 16 years in $41.2 \%$. The age of onset of substance abuse is between 18 and 27 years in $75 \%$; drug trafficking is the most committed crime in $65.9 \%$, followed by kidnapping $(9.1 \%)$ and rape $(6.8 \%)$.

3) With low levels of domestic violence and substance abuse (domestic violence as the relevant problem) the inmate's age is between 28 and 37 years at $39 \%$; $36.6 \%$ have completed high school, and the age of fist job is between 13 and 16 years at $39.6 \%$. The age of onset of substance abuse is between 18 and 27 years in $75 \%$; drug trafficking is the most committed crime in $64.8 \%$, followed by homicide (11.4\%) and theft (6.8\%).

4) With low levels of domestic violence and addictions (addictions as the relevant problem) the inmate's age is between 28 and 37 years old at $34 \% ; 47.2 \%$ have completed high school and the age of fist job is between 13 and 16 years in $36.4 \%$. The age of onset of substance abuse is between 18 and 27 years in $84.4 \%$; drug trafficking is the most committed crime in $74.3 \%$, followed by homicide (9.5\%) and kidnapping (5.4\%).

Figure 9 shows contrast between domestic violence vs. alcohol consumption and substance abuse; CP2 and CP3 were related, obtaining the following scatter plot.

The analysis of the quadrants showed that:

1) With low levels of domestic violence and addictions (substance abuse as addictive profile), the inmate's age is between 28 and 37 years old at $41.8 \%$; $70 \%$ have completed high school, and the age of fist job is between 9 and 16 in $66.6 \%$. 


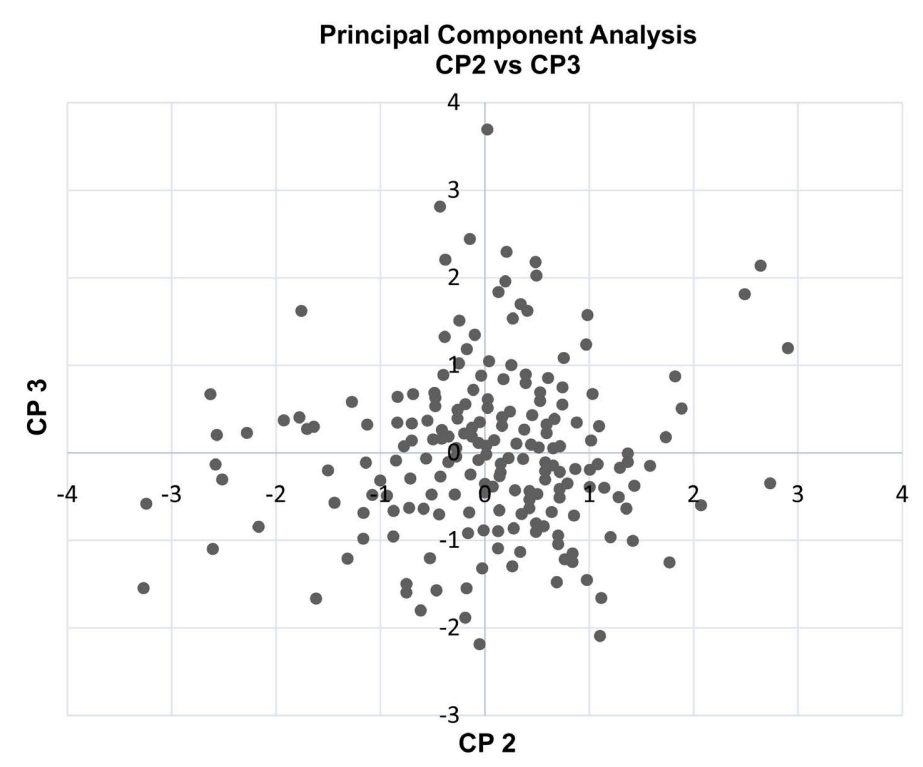

Figure 9. Principal component analysis: CP2 vs. CP3.

The age of onset of substance abuse is between 18 and 27 in $85.7 \%$; drug trafficking is the most committed crime in $62.8 \%$, followed by kidnapping (14.6\%) and homicide (12.5\%).

2) With high levels of domestic violence and addictions (substance abuse as addictive profile), the inmate's age is between 28 and 47 years in $66.7 \%$; $76.7 \%$ have completed high school, and the age of fist job is between is between 13 and 16 in $44.2 \%$. The age of onset of substance abuse is between 18 and 27 in $86.4 \%$; drug trafficking is the most committed crime in $75 \%$, followed by homicide (11.3\%) and rape (5\%).

3) With high levels of domestic violence and low levels of addictions (alcohol consumption as addictive profile), the inmate's age is between 28 and 37 at $38.9 \%$; $69.8 \%$ have completed high school, and the age of fist job is between 13 and 16 years in $39.3 \%$. The age of onset of substance abuse is between 18 and 27 in $75 \%$; drug trafficking is the most committed crime in $69.6 \%$, followed by theft (6.5\%) and rape $(6.5 \%)$.

4) With low levels of domestic violence and high levels of addictions (alcohol consumption as addictive profile), the inmate's age is between 28 and 37 at $37 \%$; $36.4 \%$ have completed high school, and the age of the first job is between 13 and 16 in $40.6 \%$. The age of onset of substance abuse is between 18 and 27 in 75\%; drug trafficking is the most committed crime in $62.8 \%$, followed by homicide (12.8\%).

\section{Discussion and Conclusions}

Crime in our country is comprised of numerous social and political conditions, which determine the prison environment. In this respect, the social circumstances related to criminal behavior are the presence of domestic violence and substance intake; these characteristics, in addition to the sociodemographic cha- 
racteristics of the vulnerable population, facilitate criminal behavior.

The inmate population in this research presents a specific profile, namely: adults, cohabiting with a couple, middle scholarship, a monthly income of $\$ 157$ USD or more, the motivation to work in adolescence in order to support their households economically. By knowing these circumstances, it is possible to formulate prevention and intervention strategies that facilitate the social balance and the reintegration of the subject to society, such as educational programs regarding substance intake, domestic violence, and stress coping strategies.

According to the results, it is observed that $52.4 \%$ of the population does not have a sentence of imprisonment; it is in process. Also, this portion of male inmates has been in jail for between 7 and 20 years, which suggests a high rate of imprisonment. The change of environment that means the entrance to the penitentiary situation supposes the appearance of depressive symptomatology, diminished with the appearance of this phenomenon. The imprisonment explains how the individual, when entering prison, assumes a specific code of conduct and values within the imprisonment culture, without being aware of it.

In the penitentiary system, people of different social groups, ideologies, levels of education, customs, and traditions coexist, and power relations are generated by the imposition of laws, norms, rules, and different social patterns from their daily life because they are forced to live together.

It is important to notice that $41.6 \%$ of the surveyed population does not have sentence imprisonment; it is in process. This means that most of the prison population in CEFERESO 7 in Durango has not been found guilty yet. In this regard, the new accusatory criminal system has begun in Mexico; 15 states of the Republic already apply the National Code of Criminal Procedures. One of the most important changes established by this new law is that the conflicts which result from the commission of the crimes will no longer find a solution in pre-trial detention. This action arises because the current system does not take into consideration the fact that prison is the result of a trial with a guilty subject; otherwise, the accused has to be treated as innocent, avoiding their deprivation of liberty. The benefits of these determinations are multiple: the reduction of saturation in penitentiary centers, favoring the establishment of reinsertion and treatment strategies (emotional, against addictions, etc.), guaranteeing the presumption of innocence.

An important datum noticed in the results regards the most committed crime: drug trafficking. In Mexico, drug trafficking is a lifestyle for many because it represents a source of work with economic remuneration that helps large families to subsist. The lack of economic resources and the low educational level provoke criminal behaviors related to the sale of illicit substances.

In Mexico, the General Law of Social Development (LGDS) states that poverty must be measured in eight dimensions (not only income): educational backwardness, access to health, access to social security, quality and housing spaces, access to basic services, access to food, degree of social cohesion, and income. These poverty indicators from 2014 show that in Mexico there are 55.3 million 
poor people, equivalent to $46.2 \%$ of the population, whose human rights are violated (Gómez, 2016) [2].

As indicated in the 2008 reform to the national penitentiary system, reintegration is the main objective of prisons in Mexico, preventing recidivism of criminal conduct. In addition to these efforts by the authorities, it is indispensable that effective tactics be applied before, during and after imprisonment to favor the biological, psychological and spiritual development of Mexican people.

\section{Conflicts of Interest}

The authors declare no conflicts of interest regarding the publication of this paper.

\section{References}

[1] Camacho-Valadez, D. and Pérez-García, M. (2013) El perfil demográfico/antropométrico del agresor denunciado de violencia de género al norte de México: Estudio descriptivo. Cuadernos de Medicina Forense, 19, 29-32. https://doi.org/10.4321/S1135-76062013000100005

[2] Gómez, K.R. (2016) El análisis dinámico de la pobreza en México como nueva agenda de investigación: un estado de la cuestión como base para futuras indagaciones. $R e$ vista Mexicana de Análisis Político y Administración Pública, 5, 29.

[3] Cueva, G. (2012) Violencia y adicciones: problemas de salud pública. Revista Peruana de Medicina Experimental y Salud Publica, 29, 99-103. https://doi.org/10.17843/rpmesp.2012.291.315

[4] Mitofsky, C. (2013) Décima segunda encuesta nacional sobre percepción de inseguridad ciudadana en México. Encuesta Nacional de Viviendas, Consulta Mitofsky, México City.

[5] Observatorio Nacional Ciudadano (2017) Reporte sobre delitos de alto impacto, enero 2017. Observatorio Nacional Ciudadano Seguridad, Justicia y Legalidad, México. https://onc.org.mx

[6] Dumont, D.M., Brockmann, B., Dickman, S., Alexander, N. and Rich, J.D. (2012) Public Health and the Epidemic of Incarceration. Annual Review of Public Health, 33, 325-339. https://doi.org/10.1146/annurev-publhealth-031811-124614

[7] Romero-Abrio, A., Villarreal-González, M.E., Callejas-Jerónimo, J.E., Sánchez-Sosa, J.C. and Musitu, G. (2019) La violencia relacional en la adolescencia: Un análisis psicosocial. Psicología y Salud, 29, 103-113. https://doi.org/10.25009/pys.v29i1.2572

[8] Lee, R.D., Fang, X. and Luo, F. (2013) The Impact of Parental Incarceration on the Physical and Mental Health of Young Adults. Pediatrics, 131, e1188-e1195. https://doi.org/10.1542/peds.2012-0627

[9] Alvarado-Zaldívar, G., Salvador-Moysén, J., Estrada-Martínez, S. and TerronesGonzález, A. (1998) Prevalencia de violencia doméstica en la ciudad de Durango. Salud Pública de México, 40, 481-487. https://doi.org/10.1590/S0036-36341998000600004

[10] Vicario, M.H. and Júdez, J. (2007) Adolescencia de alto riesgo. Consumo de drogas y conductas delictivas. Pediatría Integral, 11, 895-910.

[11] Palmer, E.J. and Connelly, R. (2005) Depression, Hopelessness and Suicide Ideation among Vulnerable Prisoners. Criminal Behaviour and Mental Health, 15, 164-170. https://doi.org/10.1002/cbm.4 
[12] Gussak, D. (2007) The Effectiveness of Art Therapy in Reducing Depression in Prison Populations. International Journal of Offender Therapy and Comparative Criminology, 51, 444-460. https://doi.org/10.1177/0306624X06294137

[13] Baillargeon, J., Contreras, S., Grady, J.J., Black, S.A. and Murray, O. (2000) Compliance with Antidepressant Medication among Prison Inmates with Depressive Disorders. Psychiatric Services, 51, 1444-1446. https://doi.org/10.1176/appi.ps.51.11.1444

[14] Prins, S.J. (2014) Prevalence of Mental Illnesses in US State Prisons: A Systematic Review. Psychiatric Services, 65, 862-872.

https://doi.org/10.1176/appi.ps.201300166

[15] Reingle Gonzalez, J.M. and Connell, N.M. (2014) Mental Health of Prisoners: Identifying Barriers to Mental Health Treatment and Medication Continuity. American Journal of Public Health, 104, 2328-2333.

https://doi.org/10.2105/AJPH.2014.302043

[16] Villagrán, L. (2013) The Victims' Movement in Mexico. Building Resilient Communities in Mexico: Civic Responses to Crime and Violence, San Diego.

[17] Martínez Lanz, P., Betancourt, O.D., Burns de la Torre, A. and Rendón Beyruti, L. (2012) Factores de riesgo asociados a la delincuencia masculina en México: Un estudio a reclusos de un centro de readaptación social varonil. Revista Criminalidad, 54, 359-377.

[18] Martínez Lanz, P. (2017) Delincuencia: Una aproximación psicológica a sus casusas y consecuencias. 2nd Edition, Ed. Porrúa, México, 2017 Porrúa.

[19] Martínez Lanz, P. (2018) Repercusión de la violencia intrafamiliar en las conductas delictivas. Medicina y Ética 2018/4, Vol. XXIX Octubre-diciembre, 993-1017.

[20] Martínez-Lanz, P., Sánchez-Guerrero, A. and Hernández-Valdez, M.P. (2020) Cultural Factors Associated with Criminal Male Behavior in Inmate Population. Advances in Social Sciences Research Journal, 7, 274-284.

https://doi.org/10.14738/assrj.71.7623 